\title{
Osmoregulation in Azospirillum brasilense: glycine betaine transport enhances growth and nitrogen fixation under salt stress
}

\author{
N. RIOU and D. LE RUdULIER* \\ Laboratoire de Biologie Végétale et Microbiologie, URA CNRS 1114, Faculté des Sciences et des Techniques, \\ Université de Nice-Sophia Antipolis, Parc Valrose, 06034 Nice Cedex, France
}

(Received 21 December 1989; revised 12 March 1990; accepted 12 April 1990)

\begin{abstract}
Addition of glycine betaine (1 mM) stimulated aerobic growth of Azospirillum brasilense Sp 7 in the presence of $\mathrm{O} \cdot 3 \mathrm{M}-\mathrm{NaCl}$. The nitrogenase activity of whole cells was particularly sensitive to salt stress, being almost totally inhibited in the presence of the same concentration of salt. Added glycine betaine strongly enhanced nitrogen fixation activity under salt stress. Under such conditions, maximal nitrogenase activity was obtained at a $\mathrm{pO}_{2}$ value (1 kPa) that inhibits nitrogen fixation activity in the absence of salt. We demonstrated the presence of a highaffinity transport system for glycine betaine, with an apparent $K_{\mathrm{m}}$ of $10 \mu \mathrm{M}$. The osmolarity of the medium regulated the activity of the transport system. The maximal transport rates were 4 and $20 \mathrm{nmol} \mathrm{min}^{-1}$ (mg protein) ${ }^{-1}$ in cells grown in low-salt and high-salt medium, respectively. A high intracellular concentration of glycine betaine $(480 \mathrm{mM})$ was observed only at a high osmolarity (0.3 M-NaCl). Glycine betaine uptake was significantly reduced in osmotically shocked cells and a glycine betaine binding activity was detected in the crude periplasmic shock fluid. This suggests a transport mechanism involving a periplasmic glycine betaine binding protein. $A$. brasilense was unable to use the transported glycine betaine as a carbon- or nitrogen-source, in low- or high-salt medium. Intracellular glycine betaine was not catabolized.
\end{abstract}

\section{Introduction}

Azospirillum brasilense is a Gram-negative aerobic bacterium which has a tendency to grow in close association with the roots of graminaceous plants, including some important crop plants. $A$. brasilense fixes nitrogen and has been used as bacterial fertilizer (Von Bülow \& Döbereiner, 1975; Okon \& Kapulnik, 1986). In addition, in response to Azospirillum inoculant, a significant enhancement of lateral roots and root hair proliferation (Tien et al., 1979) is concomitant with an increase in mineral uptake by the plant (Lin et al., 1983). It was proposed that the stimulation of plant growth could be explained by phytohormone production.

In the natural environment, salinity affects microbial activity and plant growth. Substantial areas of agricultural potential in the tropics and sub-tropics are affected by salt. Many organisms that face saline or dry environments accumulate quaternary ammonium compounds such as glycine betaine. This betaine accumulates in higher plants including chenopods, composites and several cereals and grasses in response to salinity (Wyn Jones \& Storey, 1981; Hanson \& Hitz, 1982). Indirect evidence indicates the adaptative value of betaine accumulation in salt-stressed and water-stressed plants (Hanson \& Grumet, 1984). Glycine betaine has also been shown to be an effective osmoprotectant and to accumulate to high concentrations in both halophilic bacteria and in the enteric bacteria Escherichia coli, Salmonella typhimurium and Klebsiella pneumoniae in response to osmotic stress (Imhoff \& Rodriguez-Valera, 1984; Le Rudulier \& Bouillard, 1983; Perroud \& Le Rudulier, 1985). Furthermore, glycine betaine plays a key role in osmoregulation in Rhizobium meliloti, the root nodule symbiont of alfalfa (Le Rudulier \& Bernard, 1986). In contrast to $E$. coli, glycine betaine can function in $R$. meliloti as a carbon, nitrogen and energy source (Bernard et al., 1986; Smith et al., 1988).

Recently, more attention has been given to plantassociated diazotrophs showing salt tolerance or enhanced growth at high osmolarity. Salt tolerant strains of Azospirillum halopraeferans have been isolated from the root surface of Leptochloa fusca (L.) Kunth (Kallar grass) grown on salt-affected low-fertility soils (Reinhold et al., 1987). However, little information is available about the osmoregulatory properties and the effect of salinity on the nitrogenase activity of Azospirillum strains (Hartmann, 1988; Jena et al., 1988). In this study, the 
consequences of salt stress on the growth and nitrogenfixation activity of $A$. brasilense were analysed. Additionally, the beneficial effect of glycine betaine, and some characteristics of its uptake, are described.

\section{Methods}

Bacterial strain and cultures. Azospirillum brasilense $\mathrm{Sp} 7$ (ATCC 2914) was kindly supplied by Dr C. Elmerich (Institut Pasteur, Paris, France). Cultures were maintained in nutrient broth (rich medium) as described by Gauthier \& Elmerich (1977). The cells were grown aerobically at $30^{\circ} \mathrm{C}$ in $\mathrm{K}$ medium (minimal medium) according to Franche \& Elmerich (1981), except that the carbon source used was sodium lactate $\left(5 \mathrm{~g} \mathrm{l}^{-1}\right)$ instead of malate. The nitrogen source was $20 \mathrm{mM}-\mathrm{NH}_{4} \mathrm{Cl}$. The osmolarity of the $\mathrm{K}$ medium was increased by adding $\mathrm{NaCl}$ at the concentrations indicated. The osmotic pressure of the different media was measured by freezing-point depression as described previously (Perroud \& Le Rudulier, 1985). Solutions of glycine betaine were sterilized by filtration on $0.22 \mu \mathrm{m}$ pore-size filters. When glycine betaine was used as the sole nitrogen source, it was added at $10 \mathrm{mM}$. Growth was monitored as the optical density at $420 \mathrm{~nm}$ after suitable dilution with the growth medium. The protein content was quantified by the Lowry method. An $\mathrm{OD}_{420}$ of 1.0 corresponded to $0.1 \mathrm{mg}$ protein $\mathrm{ml}^{-1}$ in minimal medium without adding $\mathrm{NaCl}$. A correcting factor was used when the cells were grown in the presence of $\mathrm{NaCl}$.

Assay for nitrogen fixation. Nitrogen fixation was assayed in $\mathrm{K}$ medium, devoid of ammonia, described by Franche \& Elmerich (1981). Aliquots ( $1 \mathrm{ml})$ of washed cells from preculture in $\mathbf{K}$ medium were inoculated into $60 \mathrm{ml}$ flasks containing $8 \mathrm{ml}$ of nitrogen-free medium. The flasks were sealed with stoppers and flushed with argon. Oxygen was adjusted to the appropriate concentration $\left(\mathrm{pO}_{2} 0-2 \mathrm{kPa}\right)$. The cultures were incubated for $4 \mathrm{~h}$ at $30^{\circ} \mathrm{C}$ with shaking (150 r.p.m.), and $5 \mathrm{ml}$ acetylene were then added. Ethylene production was measured $30 \mathrm{~min}$ and $1 \mathrm{~h}$ later with a Packard (model 427) gas chromatograph equipped with a flame ionization detector and a Porapack $\mathrm{T}$ column $(200 \times 0.3 \mathrm{~cm})$ equilibrated at $60^{\circ} \mathrm{C}$.

Transport assays. When the culture density in $\mathrm{K}$ medium reached an $\mathrm{OD}_{420}$ of $0.5-0.8$, the cells were harvested by centrifugation, washed twice with the growth medium, and resuspended to a concentration of $0.1 \mathrm{mg}$ cell protein $\mathrm{ml}^{-1}$ in the same solution. Individual uptake experiments were done aerobically at $30^{\circ} \mathrm{C}$ as described by Perroud $\&$ Le Rudulier (1985). Each assay contained $2.08 \mathrm{kBq}\left[\right.$ methyl $\left.{ }^{14} \mathrm{C}\right]$ glycine betaine and nonradioactive glycine betaine to produce the appropriate specific activity. [methyl ${ }^{14} \mathrm{C}$ ]Glycine betaine was prepared from $\left[\right.$ methyl ${ }^{14} \mathrm{C}$ ]choline as described previously (Perroud \& Le Rudulier, 1985). [methyl $\left.{ }^{14} \mathrm{C}\right]$ Choline $\left(2.15 \mathrm{MBq} \mu \mathrm{mol}^{-1}\right)$ was purchased from Amersham. Assays with $\left[\mathrm{U}-{ }^{14} \mathrm{C}\right]$ succinic acid contained $1 \mu \mathrm{M}$ radioactive substrate $(4.88 \mathrm{kBq})$. [U-14 $\mathrm{C}]$ Succinic acid $\left(5.55 \mathrm{MBq}^{14} \mathrm{~mol}^{-1}\right)$ was obtained from CEA (France). Each assay was done at least in triplicate, and each experiment was repeated with at least two independent cell suspensions.

Measurement of intracellular volume. The intracellular aqueous volumes were determined by the technique of Stock et al. (1977) using [carboxyl $\left.-{ }^{14} \mathrm{C}\right]$ dextran and $\left[{ }^{3} \mathrm{H}\right]$ water purchased from New England Nuclear and CEA (France), respectively. Values were $2.2 \pm 0.3$ and $0.9 \pm 0.3 \mu \mathrm{l}$ (mg protein $)^{-1}$ for cells growing in minimal medium and minimal medium containing $0.3 \mathrm{M}-\mathrm{NaCl}$, respectively.

Osmotic shock and binding assays. Periplasmic fractions were isolated from the cells by cold osmotic shock according to the method of Neu \& Heppel (1965). Periplasmic proteins were concentrated by ultra- filtration on Amicon YM 10 membranes. Binding activity in shock fluid was detected by an equilibrium dialysis technique (Argast \& Boos, 1979; May et al., 1986) in the presence of $5 \mu \mathrm{M}-\left[\right.$ methyl ${ }^{-14} \mathrm{Clglycine}$ betaine. The protein concentration was $0.5 \mathrm{mg} \mathrm{ml}^{-1}$ and samples $(20 \mu \mathrm{l})$ were taken in duplicate every $30 \mathrm{~min}$, over $6 \mathrm{~h}$. The amount of glycine betaine remaining was determined by scintillation counting. As an alternative, the binding assays were done by the filter binding procedure (Richarme \& Kepes, 1983). Samples of periplasmic shock fluid $(100-200 \mu \mathrm{g}$ protein) were incubated for $30 \mathrm{~min}$ with the appropriate amount of $\left[{ }^{14} \mathrm{C}\right]$ glycine betaine $(2.5 \mathrm{kBq}$; $\left.2.15 \mathrm{MBq} \mu \mathrm{mol}^{-1}\right)$. Proteins were precipitated by adding $1 \mathrm{ml}$ of an icecold saturated ammonium sulphate solution, collected by filtration onto $0.45 \mu \mathrm{m}$ nitrocellulose filters, and washed four times with $1 \mathrm{ml}$ ammonium sulphate solution. The radioactivity of the filters was determined in a scintillation counter.

Fate of glycine betaine. Cells were harvested in mid-exponential phase and incubated aerobically at $30^{\circ} \mathrm{C}$ in a Warburg flask with a $\mathrm{KOH}$ trap $(0.2 \mathrm{ml}, 6 \mathrm{M})$. [methyl $\left.{ }^{14} \mathrm{C}\right] \mathrm{Glycine}$ betaine was added to a final concentration of $0.1 \mu \mathrm{M}$. At intervals, the cells were collected on nitrocellulose filters $(0.22 \mu \mathrm{m}$ pore size) and extracted with $70 \%(\mathrm{v} / \mathrm{v})$ ethanol as described previously (Bernard et al., 1986). The radioactivity of each resulting fraction ( $\mathrm{KOH}$, ethanol-insoluble, ethanol-soluble) was measured by liquid scintillation. Analysis of the intracellular products was done by high-voltage electrophoresis for $60 \mathrm{~min}$ at $40 \mathrm{~V} \mathrm{~cm}^{-1}$ with Whatman $3 \mathrm{MM}$ filter paper moistened in $3 \%(\mathrm{v} / \mathrm{v})$ formic acid, pH 2.0 (Le Rudulier \& Bouillard, 1983).

\section{Results}

\section{Osmoprotection of $A$. brasilense $S p 7$ by exogenous glycine betaine}

The effects of $\mathrm{NaCl}$ concentration on the growth rate of A. brasilense are shown in Fig. 1. Addition of $0.3 \mathrm{M}-\mathrm{NaCl}$ increased the doubling time of the cells from $2 \mathrm{~h}$ in the

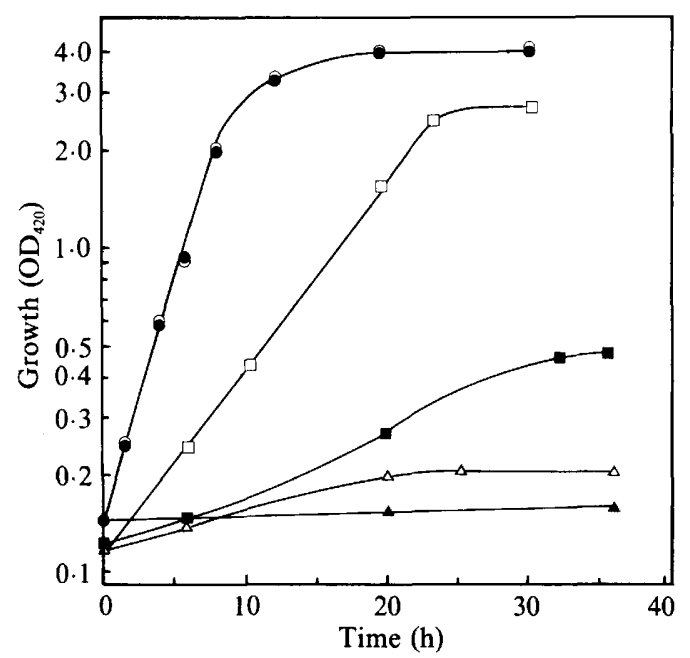

Fig. 1. Effect of exogenous glycine betaine on the growth of A. brasilense $\mathrm{Sp} 7$ in media containing different $\mathrm{NaCl}$ concentrations. Cell growth was estimated as the $\mathrm{OD}_{420}$; values are plotted as a function of incubation time. Cells were grown in the presence of $1 \mathrm{~mm}$-glycine betaine (open symbols) or in the absence of glycine betaine (filled symbols). $O$, Minimal medium; $\square$, minimal medium plus $0.3 \mathrm{M}-\mathrm{NaCl} ; \triangle$, minimal medium plus $0.5 \mathrm{M}-\mathrm{NaCl}$. 
minimal medium to $15 \mathrm{~h}$. Additionally, the maximal cell density $\left(\mathrm{OD}_{420}\right)$ was reduced considerably - from 4 units in the absence of $\mathrm{NaCl}$ to only 0.5 unit in the presence of $0.3 \mathrm{M}-\mathrm{NaCl}$. Increasing the salt concentration to $0.5 \mathrm{M}$ totally inhibited growth.

Addition of glycine betaine at a concentration of $1 \mathrm{mM}$, which causes maximal stimulation of the growth rate of enteric bacteria and $R$. meliloti in media of high osmolarity (Le Rudulier \& Bouillard, 1983; Bernard et al., 1986), did not modify the growth rate and yield of $A$. brasilense in low-salt medium. However, in the presence of $0.3 \mathrm{M}-\mathrm{NaCl}$, addition of glycine betaine produced an almost 3-fold stimulation of growth, lowering the doubling time to $5.5 \mathrm{~h}$. Furthermore, the maximal optimal density of the culture reached 3 units after only $24 \mathrm{~h}$ of growth. In the presence of $0.5 \mathrm{M}-\mathrm{NaCl}$, the stimulation was less and the cells achieved a very low final density $\left(\mathrm{OD}_{420}=0 \cdot 25\right)$.

\section{Enhancement of nitrogen fixation activity by glycine betaine in salt-stressed $A$. brasilense}

Fig. 2 shows the $\mathrm{pO}_{2}$ profile of the specific nitrogenase activity of whole cells grown in media of low or high osmolarity $(0.3 \mathrm{M}-\mathrm{NaCl})$, with or without $1 \mathrm{mM}$-glycine betaine. With cells grown in minimal medium (Fig. $2 a$ ), anaerobiosis or a high dissolved oxygen concentration $\left(\mathrm{pO}_{2} \quad 1.5 \mathrm{kPa}\right)$ almost totally inhibited nitrogenase activity. $A$. brasilense is a well-characterized microaerobic nitrogen-fixing bacterium and the optimal $\mathrm{pO}_{2}$ for nitrogen fixation was $0.4 \mathrm{kPa}$, as determined previously by $\mathrm{Fu} \&$ Burris (1989). Addition of glycine betaine did not significantly affect the nitrogen fixation activity. Addition of $0.3 \mathrm{M}-\mathrm{NaCl}$ resulted in no nitrogenase activity at low $(0.4 \mathrm{kPa})$ or high $(2 \mathrm{kPa}) \mathrm{pO}_{2}$ values, and caused $96 \%$ inhibition at the optimal $\mathrm{pO}_{2}$. Addition of glycine betaine stimulated nitrogen fixation activity greatly: the increase was 14-fold at a $\mathrm{pO}_{2}$ of $0.5 \mathrm{kPa}$ and 23-fold at a $\mathrm{pO}_{2}$ of $1 \mathrm{kPa}$. As previously observed with $K$. pneumoniae (Le Rudulier \& Bouillard, 1983), the nitrogen fixation activity of salt-stressed $A$. brasilense cells grown in the presence of glycine betaine reached about $55 \%$ of the activity measured in cells grown in lowsalt medium.

\section{Evidence for glycine betaine transport}

The time course of glycine betaine uptake in low-saltand high-salt-grown cells is shown in Fig. 3. Cells grown in minimal medium showed a low glycine betaine transport activity. The uptake was linear for approximately $15 \mathrm{~min}$ with an initial rate of $3.0 \mathrm{nmol} \mathrm{min}^{-1}$ (mg protein $)^{-1}$. After $20 \mathrm{~min}$, the uptake rate was almost nil and the transported quantity of glycine betaine was

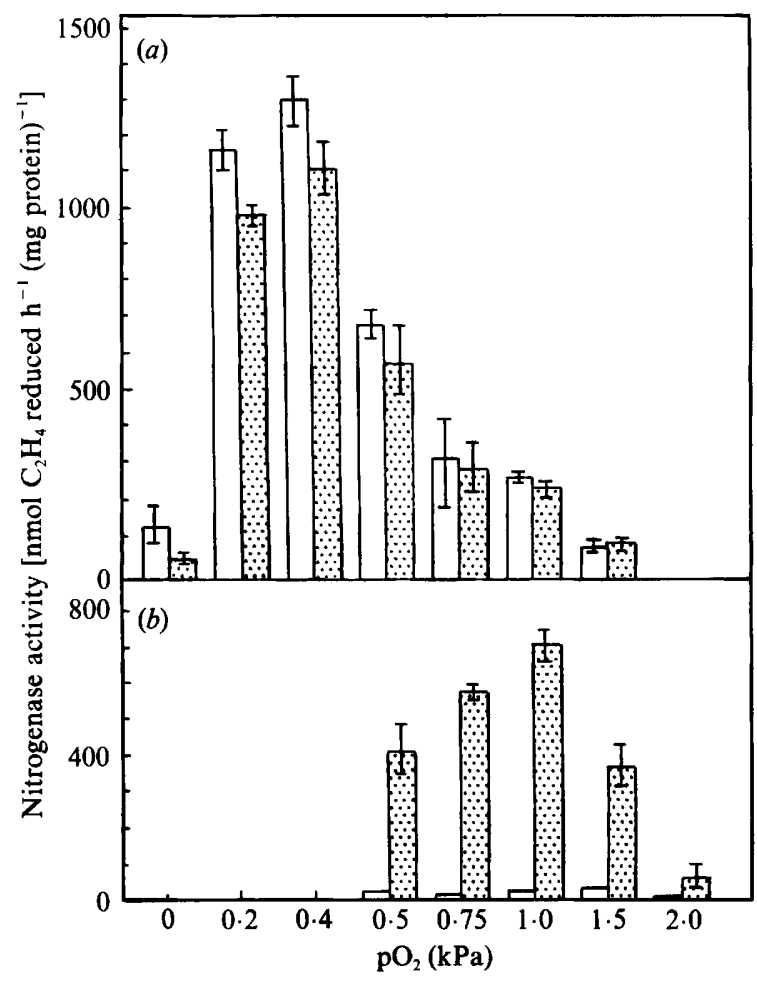

Fig. 2. Effect of $\mathrm{NaCl}, \mathrm{pO}_{2}$ and exogenous glycine betaine ( $\left.1 \mathrm{mM}\right)$ on the specific nitrogenase activity of whole cells of $A$. brasilense Sp 7 . Nitrogenase activity was measured as acetylene reduction as described in the text with cells grown in the absence of $\mathrm{NaCl}(a)$ or in the presence of $0.3 \mathrm{M}-\mathrm{NaCl}(b)$. $\mathrm{O}$, Plus glycine betaine; $\square$, no glycine betaine. The values are means of three separate experiments, with the deviation from the mean indicated.

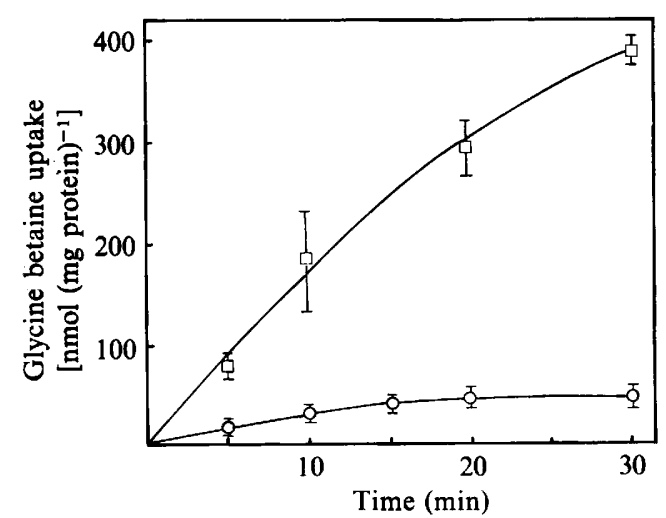

Fig. 3. Time course of $\left[\right.$ methyl $\left({ }^{14} \mathrm{C}\right]$ glycine betaine uptake by A. brasilense $\mathrm{Sp} 7$. Cells grown in the absence of $\mathrm{NaCl}$ or in the presence of $0.3 \mathrm{M}-\mathrm{NaCl}$ were incubated at $30^{\circ} \mathrm{C}$ with 30 or $200 \mu \mathrm{M}-\left[\right.$ methyl $\left.-{ }^{14} \mathrm{C}\right]-$ glycine betaine, respectively. Reactions were terminated by filtration at the time shown. The points shown are the mean values of duplicate assays from three different experiments. Vertical bars indicate \pm SD. $O$, Cells grown in minimal medium; $\square$, cells grown in minimal medium plus $0 \cdot 3 \mathrm{M}-\mathrm{NaCl}$. 
only $50 \mathrm{nmol}$ after $30 \mathrm{~min}$. Since the measured internal water volume of $A$. brasilense was $2 \cdot 15 \mu \mathrm{l}$ (mg protein) ${ }^{-1}$, the estimated intracellular concentration of glycine betaine was $23 \mathrm{~mm}$. When the cells were grown in highsalt medium ( $0.3 \mathrm{M}-\mathrm{NaCl})$, a strong stimulation of uptake was observed. The rate of glycine betaine transport was constant for approximately $10 \mathrm{~min}$ with a maximal velocity of $18 \mathrm{nmol} \mathrm{min}{ }^{-1}$ (mg protein) $)^{-1}$. The initial rapid rate was followed by a slower uptake, and after $30 \mathrm{~min}$ the total quantity transported was $380 \mathrm{nmol}$ (mg protein ${ }^{-1}$ ), which was 7.6 times greater than the quantity transported by cells grown in minimal medium. In the presence of $0.3 \mathrm{M}-\mathrm{NaCl}$, the cellular water volume of the cells was only $0.85 \mu \mathrm{l}(\mathrm{mg} \text { protein })^{-1}$, and the estimated internal concentration of glycine betaine reached $480 \mathrm{~mm}$, which represented a 21 -fold increase.

\section{Kinetics of glycine betaine transport}

To determine the concentration needed to saturate the uptake system, the kinetic parameters of glycine betaine transport by $A$. brasilense were determined with low- and high-salt-grown cells. Initial rates were calculated at 2 and $10 \mathrm{~min}$ at substrate concentrations from 5-200 $\mu \mathrm{M}$. Transport was a saturable function of substrate concentration. Double-reciprocal plots gave a straight line, indicating that uptake follows typical Michaelis-Menten kinetics. The maximal velocities were $4 \pm 1$ and $20 \pm 3 \mathrm{nmol} \mathrm{min}^{-1}$ (mg protein) ${ }^{-1}$ with cells grown in minimal medium and $0.3 \mathrm{M}-\mathrm{NaCl}$, respectively. Under both conditions, the apparent $K_{\mathrm{m}}$ was $10 \pm 2 \mu \mathrm{M}$. Uptake tests at higher or lower substrate concentrations failed to show the presence of another transport system.

\section{Periplasmic glycine betaine binding activity}

Recent studies have identified a glycine betaine binding periplasmic protein as a product of the proU locus which encodes the osmoregulatory transport system for glycine betaine in both E. coli and S. typhimurium (May et al., 1986; Barron et al., 1987; Faatz et al., 1988; Higgins et $a l .$, 1987). To determine whether periplasmic proteins from $A$. brasilense might function as binding proteins for glycine betaine, we used three technical approaches. First, the effect of an osmotic cold shock on glycine betaine uptake was studied (Table 1). Uptake was strongly inhibited $(80 \%$ inhibition) by this treatment. Also, uptake of glycine betaine dramatically decreased from 12.4 to $0.9 \mathrm{nmol} \mathrm{min}^{-1}$ (mg protein) ${ }^{-1}$ after the cold shock alone. This result pointed out the necessity of a control of this type, which is very often omitted. Conversely, the cold osmotic shock did not significantly modify the uptake of succinic acid, a substrate transported via a system which is not binding-proteindependent. Second, to investigate whether a glycine betaine binding protein was released by osmotic shock, substrate-binding experiments were done with concentrated shock fluid using the filter-binding procedure described in Methods. Periplasmic glycine betaine binding activity was very low [45 pmol (mg protein $)^{-1}$ ] when the cells were grown at low osmolarity, and approximately 6-fold higher when the cells were grown in the presence of $0.3 \mathrm{M}-\mathrm{NaCl}$. Third, in order to confirm these results, we measured the binding of $\left[\right.$ methyl $\left.{ }^{14} \mathrm{C}\right]-$ glycine betaine to periplasmic proteins using a dialysis technique (Argast \& Boos, 1979) based on the retention phenomenon of binding proteins. Fig. 4 shows a rapid, linear exit of free glycine betaine from a dialysis bag that contained only buffer or a periplasmic fraction obtained from cells grown in minimal medium. When periplasmic proteins prepared from cells grown in the presence of $0 \cdot 3 \mathrm{M}-\mathrm{NaCl}$ were used, there was an initial rapid efflux of excess glycine betaine followed by a much slower efflux which represents the dissociation of bound substrate. All these results strongly suggest that a binding protein is involved in glycine betaine transport in $A$. brasilense Sp 7.

Table 1. Effect of an osmotic cold shock on $\left[\right.$ methyl $\left.{ }^{14} \mathrm{C}\right]$ glycine betaine uptake and $\left[U-{ }^{14} \mathrm{C}\right]$ succinic acid uptake in $\mathrm{A}$. brasilense

Uptake of $10 \mu \mathrm{M}-\left[\right.$ methyl $\left.{ }^{-14} \mathrm{C}\right]$ glycine betaine and $1 \mu \mathrm{M}-\left[\mathrm{U}-{ }^{14} \mathrm{C}\right]$ succinic acid was measured in control and shocked cells grown in the presence of $0 \cdot 3 \mathrm{M}-\mathrm{NaCl}$. Control cells were subjected to the same treatment as shocked cells, except for the osmotic shock, and were used immediately for uptake measurements. Mean results of duplicates are shown $\pm \mathrm{SD}$.

\begin{tabular}{|c|c|c|c|c|c|}
\hline \multirow[b]{2}{*}{$\begin{array}{l}\text { Time } \\
(\min )\end{array}$} & \multicolumn{3}{|c|}{$\begin{array}{l}\text { Glycine betaine uptake } \\
\left.\text { [nmol (mg protein) })^{-1}\right]\end{array}$} & \multicolumn{2}{|c|}{$\begin{array}{l}\text { Succinic acid uptake } \\
\left.[\text { pmol (mg protein })^{-1}\right]\end{array}$} \\
\hline & $\begin{array}{l}\text { Control cells } \\
\text { (A) }\end{array}$ & $\begin{array}{l}\text { Shocked cells } \\
\text { (B) }\end{array}$ & $\begin{array}{c}\text { Inhibition } \\
{[(\mathbf{A}-\mathbf{B} / \mathbf{A}) \times 100]}\end{array}$ & $\begin{array}{l}\text { Control cells } \\
\text { (C) }\end{array}$ & $\begin{array}{l}\text { Shocked cells } \\
\text { (D) }\end{array}$ \\
\hline $\begin{array}{l}0.5 \\
1.0 \\
2.0\end{array}$ & $\begin{array}{l}0.41 \pm 0.05 \\
0.94 \pm 0.05 \\
1.43 \pm 0.10\end{array}$ & $\begin{array}{l}0.24 \pm 0.05 \\
0.20 \pm 0.05 \\
0.23 \pm 0.05\end{array}$ & $\begin{array}{l}42 \% \\
79 \% \\
84 \%\end{array}$ & $\begin{array}{l}20 \pm 3 \\
43 \pm 4 \\
68 \pm 5\end{array}$ & $\begin{array}{l}26 \pm 3 \\
49 \pm 5 \\
73 \pm 5\end{array}$ \\
\hline
\end{tabular}




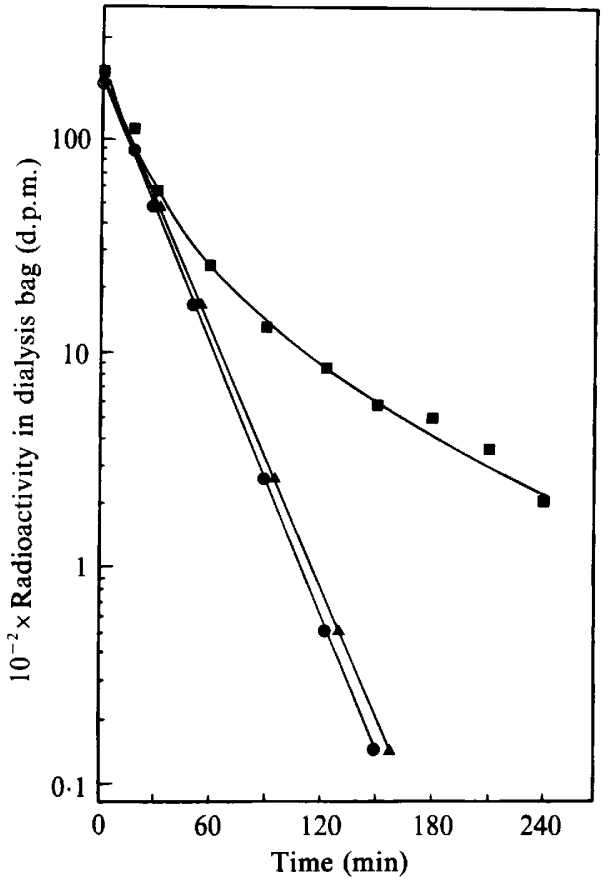

Fig. 4. Binding of $\left[\right.$ methyl $\left.-{ }^{14} \mathrm{C}\right]$ glycine betaine $(5 \mu \mathrm{M})$ to periplasmic proteins of $A$. brasilense $\mathrm{Sp} 7$. Periplasmic proteins were from cells grown in minimal medium ( $)$ or in minimal medium plus $0.3 \mathrm{M}-\mathrm{NaCl}$ (ם). A, Control experiment without periplasmic proteins in the assay. Binding was assayed in $10 \mathrm{mM}-\mathrm{Tris} / \mathrm{HCl}, \mathrm{pH} 7.5$. The amount of radioactivity remaining in the dialysis bag was plotted against time of dialysis.

\section{Fate of intracellular glycine betaine}

In nitrogen- and carbon-free minimal medium, addition of glycine betaine $(10 \mathrm{mM})$ did not support growth. Incorporation of $\mathrm{NH}_{4} \mathrm{Cl}(20 \mathrm{mM})$ into this medium also failed to promote growth. With lactate only $\left(5 \mathrm{~g} \mathrm{l}^{-1}\right)$ some growth was observed but the presence of glycine betaine had no additional effect. It was likely that glycine betaine cannot be metabolized by the cells.

The fate of intracellular glycine betaine in low- and high-salt grown cells was investigated. Cells were incubated with $\left[\right.$ methyl $-{ }^{14}$ C]glycine betaine for $1 \mathrm{~h}$, transferred into non-radioactive medium for $6 \mathrm{~h}$, and then extracted with ethanol. The radioactivity found in the ethanol-insoluble fraction representing cellular material was extremely low; $91 \%$ and $95 \%$ of the label remained in the ethanol-soluble fraction obtained from low- or high-salt-grown cells, respectively. Electrophoretic analysis of this soluble fraction revealed only a single labelled compound identified as glycine betaine itself. Similar results were obtained after $24 \mathrm{~h}$ incubation in non-radioactive high-salt medium. These experiments indicate that intracellular glycine betaine is not catabolized by $A$. brasilense.

\section{Discussion}

Azospirillum strains are widely distributed in saltaffected soils in Pakistan and Brazil (Reinhold et al., 1987). Among the nitrogen-fixing bacteria associated with the roots of a salt-tolerant grass (Leptochloa fusca $\mathrm{L}$. Kunth) used as a pioneer plant in Pakistan, a salttolerant Azospirillum, $A$. halopraeferens, has been described (Reinhold et al., 1987). In Azospirillum, osmotolerance declines in the order $A$. halopraeferens, $A$. brasilense, A. lipoferum and A. amazonense (Hartmann, 1988). However, despite increasing interest in physiological and genetic responses of bacteria to osmotic stress, very little is known about osmoregulation in Azospirillum, although Hartmann (1988) demonstrated that addition of glutamate or proline $(5 \mathrm{mM})$ and glycine betaine ( $1 \mathrm{mM})$ to minimal medium resulted in better growth at inhibitory $\mathrm{NaCl}$ concentrations in $A$. brasilense and $A$. halopraeferens, but not in $A$. lipoferum and $A$. amazonense. The results obtained in the present study demonstrate the importance of glycine betaine in both the restoration of growth and the stimulation of nitrogen fixation activity in $\boldsymbol{A}$. brasilense subjected to salt stress. At high osmolarity, exogenous glycine betaine is accumulated by the cells; the internal concentration of glycine betaine after $30 \mathrm{~min}$ of incubation with $200 \mu \mathrm{M}$ substrate reached $480 \mathrm{~mm}$. These results are similar to those obtained previously with $E$. coli and $R$. meliloti (Perroud \& Le Rudulier, 1985; Bernard et al., 1986). Consistent with this finding, stressed cells had a highaffinity transport system for glycine betaine. The $K_{\mathrm{t}}$ for glycine betaine, $10 \mu \mathrm{M}$, was not influenced by the osmolarity of the growth medium. However, the maximal velocities were 4 and $20 \mathrm{nmol} \mathrm{min}^{-1}$ (mg protein) ${ }^{-1}$ for cells grown at low salt concentrations and $0.3 \mathrm{M}-\mathrm{NaCl}$, respectively. In the presence of lower or higher substrate concentrations, no evidence was obtained for a second system of different affinity.

The regulation and activity of glycine betaine uptake has been studied in S. typhimurium and E. coli, and is similar in both. Transport is mediated by two transport systems, ProP and ProU (Cairney et al., 1985a, $b$; May et al., 1986; Barron et al., 1987). proP encodes a constitutive, low-affinity transport system whose expression is stimulated several-fold during osmotic upshock. proU encodes a high-affinity system that is strongly induced at the transcriptional level by osmolarity. Both systems are also regulated at the level of transport activity (Cairney $e t$ $a l ., 1985 a, b$; Faatz et al., 1988). The ProU system contains a periplasmic glycine betaine binding protein of $M_{\mathrm{r}} 31000$ (Higgins et al., 1987; May et al., 1986) which was purified from $E$. coli and was shown to have a $K_{\mathrm{D}}$ of $1.4 \mu \mathrm{M}$. Recently, the proU region has been shown to contain three genes, proV, proW, and proX in an operon 
(Faatz et al., 1988; Dattananda \& Gowrishankar, 1989). From the determined proU DNA sequence (Gowrishankar, 1989), the products of these genes have been deduced. The proV gene encodes a hydrophilic protein $\left(M_{\mathrm{r}} 44162\right)$ which shares considerable sequence identity with ATP-binding proteins from other periplasmic transport systems (Stirling et al., 1989; May et al., 1989). The proW gene encodes a hydrophobic polypeptide $\left(M_{\mathrm{r}} 37619\right)$ which is thought to be located in the cytoplasmic membrane. The pro $X$ gene encodes the periplasmic glycine betaine binding protein $\left(M_{\mathrm{r}} 33729\right)$.

Since the results presented here are the first evidence for glycine betaine transport in Azospirillum, it is obvious that this transport is understood much less than in the enteric bacteria. However, from our results, glycine betaine transport in $A$. brasilense appears to be dependent on a periplasmic binding protein based on the following evidence. (i) Significant reduction of glycine betaine transport activity after osmotic shock, which is associated with the concomitant release of a glycine betaine binding activity into the crude shock fluid. (ii) Binding activity is not found with low-salt-grown cells, which show very low transport activity. (iii) The kinetics of glycine betaine transport show it to be a highaffinity transport system with a $K_{\mathrm{m}}$ of $10 \mu \mathrm{M}$, comparable to the $K_{\mathrm{m}}$ of $1.3 \mu \mathrm{M}$ determined for ProU-mediated transport in $S$. typhimurium (Cairney et al., 1985b). In $A$. brasilense, this system requires further exploration. It will be of interest to identify glycine betaine binding protein(s) to understand the mechanism of betaine transport. We are at present attempting to address this question.

Only a few studies have examined the effects of $\mathrm{NaCl}$ on the acetylene-reduction activity of Azospirillum. In $A$. amazonense DSM $2787^{\mathrm{T}}$, acetylene reduction was shown to be very sensitive to the addition of salt, with $90 \%$ inhibition when only $40 \mathrm{mM}-\mathrm{NaCl}$ was added. With A. brasilense DSM $1690^{\mathrm{T}}$, and mainly with $A$. halopraeferens, increasing the $\mathrm{NaCl}$ concentration had much less effect: $28 \%$ and $24 \%$ of the activity observed in nonstressed cells was measured in the presence of $130 \mathrm{~mm}$ and $250 \mathrm{~mm}-\mathrm{NaCl}$, respectively (Reinhold et al., 1987). The nitrogenase (acetylene-reduction) activity of cultures of $A$. brasilense Sp 7 in semi-solid medium $48 \mathrm{~h}$ after inoculation was barely affected by $200 \mathrm{mM}-\mathrm{NaCl}$, whereas activity was totally abolished at $400 \mathrm{~mm}$ (Hartmann, 1988). There is good agreement between our results obtained in liquid medium and those reported by Hartmann (1988). We have no concrete data to explain this lack of nitrogenase activity in cells grown at high osmolarity. However, it is possible that the biosynthesis of nitrogenase polypeptides is strongly affected as shown previously with $K$. pneumoniae grown at a high-salt concentration (Le Rudulier et al., 1982). Other experi- ments are needed to verify this hypothesis. More importantly, we found that glycine betaine largely restored nitrogen fixation at a totally inhibitory salt concentration. However, for maximal beneficial effect of glycine betaine on acetylene-reduction activity, the oxygen concentration had to be increased from $0.4 \mathrm{kPa}$ to $1 \mathrm{kPa}$. As nitrogen fixation activity of aerobes is strictly dependent on oxygen availability, one possible explanation for high nitrogenase activity at a $\mathrm{pO}_{2}$ higher than usual might be a modification of oxygen diffusion across the bacterial envelope in high-salt-medium. However, starting from the concept of respiratory protection most extensively studied for Azotobacter, it has been proposed that respiration per se may be protective among aerobic diazotrophs (Robson \& Postgate, 1980). In A. brasilense Sp 7 the occurrence of a respiratory type of protection has been proposed (Kloss et al., 1983). We have no data to rule out the possibility that cells grown in high-salt-medium with added glycine betaine exhibited a higher respiratory rate than cells grown in low-salt medium. One alternative explanation could be that glycine betaine uptake is, to a certain extent, dependent on $\mathrm{pO}_{2}$. At a $\mathrm{pO}_{2}$ less than $0.5 \mathrm{kPa}$, the amount of glycine betaine taken up might be extremely low and not sufficient to restore nitrogen fixation activity. Increasing the $\mathrm{pO}_{2}$ could result in a stimulation of this uptake with a concomitant beneficial effect on nitrogenase activity.

The ability to catabolize glycine betaine is widespread among micro-organisms. Clostridium sporogenes is able to form trimethylamine and acetate from glycine betaine in an oxidation-reduction reaction in which betaine acts as an electron acceptor for the oxidation of certain amino acids (Naumann et al., 1983). The degradation scheme has been established as far as glycine in Agrobacterium tumefaciens (Sherr \& Law, 1965) and up to the stage of glycine, pyruvate and succinyl-CoA in Pseudomonas denitrificans (White \& Demain, 1971). In R. meliloti, glycine betaine is progressively demethylated through dimethylglycine and sarcosine to glycine. However, this catabolic system is blocked by increasing the osmotic strength of the medium (Bernard et al., 1986). In $R$. meliloti, glycine betaine can function as a carbon, nitrogen and energy source, as well as an osmoprotectant (Smith et al., 1988). In contrast, our data indicate that $A$. brasilense is unable to use glycine betaine as a source of nitrogen or carbon. This situation is similar to that observed with enteric bacteria (Perroud \& Le Rudulier, 1985). However, clear differences exist in the ability of Azospirillum species to catabolize glycine betaine, since it has been shown that strains of $\boldsymbol{A}$. lipoferum grow readily on glycine betaine as a nitrogen and carbon source, whereas $A$. amazonense and $A$. halopraeferens do not (Hartmann, 1988). 
This research was supported by the Centre National de la Recherche Scientifique. We are grateful to M. C. Poggi for excellent technical assistance. We thank H. Le Bris and M. Sigwald for skilful typing of the manuscript.

\section{References}

ARgast, M. \& Boos, W. (1979). Purification and properties of the glycerol-3-phosphate-binding protein of Escherichia coli. Journal of Biological Chemistry 254, 10931-10935.

Barron, A., Jung, J. U. \& Villarejo, M. (1987). Purification and characterization of a glycine betaine-binding protein from Escherichia coli. Journal of Biological Chemistry 262, 11841-11846.

Bernard, T., Pocard, J. A., Perroud, B. \& Le Rudulier, D. (1986). Variations in the response of salt-stressed Rhizobium strains to betaines. Archives of Microbiology 143, 359-364.

CAIRNEY, J., BOOTH, R. \& Higgins, C. F. (1985a). Salmonella typhimurium proP gene encodes a transport system for the osmoprotectant betaine. Journal of Bacteriology 164, 1218-1223.

CAIRNEY, J., BOOTH, R. \& HigGins, C. F. (1985b). Osmoregulation of the gene expression in Salmonella typhimurium: proU encodes an osmotically induced betaine transport system. Journal of Bacteriology 164, 1224-1232.

DatTananda, C. S. \& Gowrishankar, J. (1989). Osmoregulation in Escherichia coli: complementation analysis and gene-protein relationship in the proU locus. Journal of Bacteriology 171, 1915-1922.

FAATZ, E., Middendorf, A. \& Bremer, E. (1988). Cloned structural genes for the osmotically regulated binding-protein-dependent glycine betaine transport system (ProU) of Escherichia coli K12. Molecular Microbiology 2, 265-279.

Franche, C. \& Elmerich, C. (1981). Physiological properties and plasmid content of several strains of Azospirillum brasilense and Azospirillum lipoferum. Annales de Microbiologie 132A, 3-18.

FU, H. \& BURRIS, R. H. (1989). Ammonium inhibition of nitrogenase activity in Herbaspirillum seropedicae. Journal of Bacteriology 171, 3168-3175.

GAUTHIER, D. \& ELMERICH, C. (1977). Relationship between glutamine synthetase and nitrogenase in Spirillum lipoferum. FEMS Microbiology Letters 2, 101-104.

GOWRISHANKAR, J. (1989). Nucleotide sequence of the osmoregulatory proU operon of Escherichia coli. Journal of Bacteriology 171, 1923-1931.

Hanson, A. D. \& HrTZ, W. D. (1982). Metabolic responses of mesophytes to plant water deficits. Annual Review of Plant Physiology 33, 163-203.

HANSON, A. D. \& GRUMET, R. (1984). Betaine accumulation : metabolic pathways and genetics. In Cellular and Molecular Biology of Plant Stress, pp. 71-92. Edited by J. L. Key \& T. Kosuge. New York : Alan R. Liss.

HARTMANN, A. (1988). Osmoregulation properties of Azospirillum sp. In Azospirillum IV: Genetics, Physiology, Ecology, pp. 119-130. Edited by W. Kling-Muller. Berlin: Springer Verlag.

Higgins, C. F., Cairney, J., Stirling, D. A., Sutherland, L. \& BOOTH, I. R. (1987). Osmotic regulation of gene expression: ionic strength as an intracellular signal. Trends in Biochemical Sciences 12, 339-344.

IMHOFF, J. F. \& RODRIGUEZ-VALERA, F. (1984). Betaine is the main compatible solute of halophilic eubacteria. Journal of Bacteriology 160, 478-479.

Jena, P. K., Adhya, T. K. \& Rajaramamohan RaO, V. (1988). Nitrogen fixation in Azospirillum species isolated from saline paddy soils. Microbios 54, 157-163.

Kloss, M., Iwannex, K. H. \& Fendrik, I. (1983). Physiological properties of Azospirillum brasilense $\mathrm{Sp} 7$ in a malate limited chemostat. Journal of General and Applied Microbiology 29, 447-457.
LE RUDULIER, D. \& BERNARD, T. (1986). Salt tolerance in Rhizobium: a possible role for betaines. FEMS Microbiology Reviews 39, 67-72.

LE RUDULIER, D. \& BouILLARD, L. (1983). Glycine betaine, an osmotic effector in Klebsiella pneumoniae and other members of Enterobacteriaceae. Applied and Environmental Microbiology 46, 152-159.

Le Rudulier, D., Yang, S. S. \& CsonkA, L. N. (1982). Nitrogen fixation in Klebsiella pneumoniae during osmotic stress. Effect of exogenous proline or a proline over-producing plasmid. Biochimica et Biophysica Acta 719, 273-283.

LIN, W., OKon, Y. \& HARDY, R. W. F. (1983). Enhanced mineral uptake by Zea mays and Sorghum bicolor roots inoculated with Azospirillum brasilense. Applied and Environmental Microbiology 45, 1775-1779.

May, G., FaAtz, E., Villarejo, M. \& Bremer, E. (1986). Binding protein dependent transport of glycine betaine and its osmotic regulation in Escherichia coli K12. Molecular and General Genetics 205, 225-233.

May, G., FaATZ, E., Lucht, J. M., HaArdt, M., Bolliger, M. \& BREMER, E. (1989). Characterization of the osmoregulated Escherichia coli proU promoter and identification of proV as a membrane-associated protein. Molecular Microbiology 3, 1521-1532.

NaumanN, E., HipPe, H. \& GotrschalK, G. (1983). Betaine: oxidant in the Stickland reaction and methanogenesis from betaine and L-alanine by a Clostridium sporogenes-Methanosarcina barkeri co-culture. Applied and Environmental Microbiology 45, 474-483.

Neu, H. C. \& HePpel, L. H. (1965). The release of enzymes from Escherichia coli by osmotic shock and during the formation of spheroplasts. Journal of Biological Chemistry 240, 3685-3692.

OKON, Y. \& KAPULNIK, Y. (1986). Development and function of Azospirillum-inoculated roots. Plant and Soil 90, 3-16.

Perroud, B. \& LE Rudulier, D. (1985). Glycine betaine transport in Escherichia coli: osmotic modulation. Journal of Bacteriology 161, 393-401.

ReINHold, B., Hurek, T., Fendrik, I., Pot, B., Gillis, M., Kersters, K., Thielemans, S. \& De LeY, J. (1987). Azospirillum halopraeferens sp. nov., a nitrogen-fixing organism associated with roots of Kallar grass (Leptochloa fusca (L.) Kunth). International Journal of Systematic Bacteriology 37, 43-51.

RICHARME, G. \& KEPES, A. (1983). Study of binding protein-ligand interaction by ammonium sulfate-assisted adsorption on cellulose esters filters. Biochimica et Biophysica Acta 742, 16-24.

Robson, R. L. \& Postgate, J. R. (1980). Oxygen and hydrogen in biological nitrogen fixation. Annual Review of Microbiology 34, 183-207.

SHERR, L. I. \& LAw, J. M. (1965). Phosphatidylcholine synthesis in Agrobacterium tumefaciens. II. Uptake and utilization of choline. Journal of Biological Chemistry 240, 3760-3765.

Smith, L. T., Pocard, J. A., Bernard, T. \& Le Rudulier, D. (1988). Osmotic control of glycine betaine biosynthesis and degradation in Rhizobium meliloti. Journal of Bacteriology 170, 3142-3149.

Stirling, D. A., Hulton, C. S. J., Waddell, L., Park, S. F., Stewart, G. S. A. B., BOOTH, I. R. \& Higgins, C. F. (1989). Molecular characterization of the proU loci of Salmonella typhimurium and Escherichia coli encoding osmoregulated glycine betaine transport systems. Molecular Microbiology 3, 1025-1038.

Stock, J. B., Rauch, B. \& Roseman, S. (1977). Periplasmic space in Salmonella typhimurium and Escherichia coli. Journal of Biological Chemistry 252, 7850-7861.

Tien, T. M., Gaskins, M. H. \& Hubbell, D. H. (1979). Plant growth substances produced by Azospirillum brasilense and their effect on the growth of pearl millet (Pennisetum americanum L.). Applied and Environmental Microbiology 37, 1016-1024.

VON BÜLOW, J. W. F. \& DOBEREINER, J. (1975). Potential for nitrogen fixation in maize genotypes in Brazil. Proceedings of the National Academy of Sciences of the United States of America 72, 2389-2393.

WhITE, R. F. \& Demain, A. L. (1971). Catabolism of betaine and its relationship to overproduction. Biochimica et Biophysica Acta 236, 112-119.

WYN JoNes, R. G. \& StOREy, R. (1981). Betaines. In Physiology and Biochemistry of Drought Resistance in Plants, pp. 171-204. Edited by L. G. Paleg \& D. Aspinall. Sydney: Academic Press. 